\title{
The Ingots Currency in Egypt Prior to Ptolemaic Coins \\ "A Study Based on Two Unpublished Pieces \\ From The Egyptian Museum in Cairo"
}

\begin{abstract}
:
Most of the Egyptian scholars are accustomed to study coin collections dating from Alexander the Great, passing by the Ptolemaic series then the coins of Egypt under Roman and Byzantine rule. Though the period antedated the Macedonian conquest had not witnessed any official monetary system that obliged the Egyptians to deal with coins, yet there were several forms of money which circulated within the Egyptian society at the time. Metals in the form of "ingots", whether complete or fragmented, are considered to be one significant form of this money. On that account, this research aims to publish two pieces of ingots preserved in the Egyptian museum in Cairo. The nature and function of these ingots, which prevailed not only in Egypt but in most of the ancient civilizations, will be, discussed as well depending upon descriptive, historical and comparative methods.
\end{abstract}

Key words: barter system - metallic currency - ingots Egyptian coin hoards. 


\section{The Ingots Currency in Egypt Prior to Ptolemaic Coins \\ "A Study Based on Two Unpublished Pieces \\ From The Egyptian Museum in Cairo"}

Consistent with the initial stages which preceded the endorsement of minting coins in Egypt, this research aims at shedding light on the period which antedated the Greek establishment of fiscal monetary accounting in Egypt. An accurate inquisition for the miscellaneous collections of coins listed in the sixth section of the Egyptian Museum in Cairo discloses that these pieces do not only divulge the development of coins from the Ptolemaic until the Islamic era, but they also represent the preliminary phases for the emergence of coin usage in Egypt. Part of these priceless collections demonstrates how the Egyptians dealt with both metals and Greek coins antecedent to the developing of the first Egyptian official monetary system in the reign of Ptolemy I Soter (

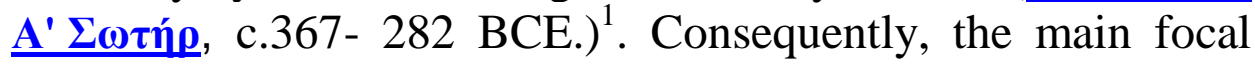
point of the current research, would be studying the nature of currency, directly antecedent to Ptolemy I, via two unpublished pieces of gold and silver ingots that are retained in the Egyptian museum in Cairo (pl. i, no.1-2). The first piece is a

${ }^{1}$ - It is preferable to put into consideration that in the last quarter of the fourth century BCE Ptolemy I took the first step toward establishing and developing a very unique system of coinage for Egypt. The advent of this king was indubitably a turning point in the monetary history of Egypt. Veraciously, the Egyptian economy before the Macedonian conquest had functioned in kind by means of grain, metals and Greek coins that were used as bullion, in such a way as will be displayed through the rest of this paper. However, after the proclamation of Ptolemy I as king in $306 \mathrm{BCE}$, there was a recognizably Ptolemaic coinage with an entirely complete series of denominations. At the time of Ptolemy's death (282 BCE) Egypt had a currency of tri-metallic system which formed the first stage of what was called latter by the numismatists "the Ptolemaic series".

Colburn, H.P., "The Role of Coinage in the Political Economy of Fourth Century Egypt", in: Ptolemy I and the Transformation of Egypt, 404-282 BCE, ed. by: Mckechnie, P. \& Cromwell, Boston, J.,Brill, 2018, p.70. Reden, S.V., Money in Ptolemaic Egypt from the Macedonian Conquest to the End of the Third Century BC., Cambridge, Cambridge University Press, 2010, p.38. 
rectangular fragment of gold, while the second is a quasi-round silver cake ingot. In spite of the fact, that the museum preserves just one gold and around fifteen silver pieces, the researcher was not allowed to study except one silver specimen only. Nevertheless, it is believed that the two pieces under study are adequate to discuss what is termed generally as "Metallic Currency"1, and specifically as "Ingots Currency", prior to the evolution of the official coins in Egypt.

It cannot be justified to ignore the barter system, which prevailed amid all the prehistoric communities, on discussing such a form of currency in ancient Egypt. We will attempt to delve deep into discussing the progression of bartering system, outside and inside Egypt, until it came to the point of utilizing metals to facilitate the exchange process.

\section{Primitive Barter}

It is widely well-known that bartering was the primary method of transactions for the daily life interactions among the members in ancient societies. Accordingly, personal movable property, numerous goods and amenities were incessantly exchanged in a simple manner. This uncomplicated barter system, which is generally known as "Silent Trade" or "Primitive Market"3, was the initial stage of trading accomplished in the absence of any medium of exchange, or in other words, without any common denominator ${ }^{4}$. In the course of the fifth century BCE., Herodotus of Halicarnassus

1 - Ridgeway, W., Origin of Metallic Currency and Weight Standards, Cambridge, Cambridge University Press, 1892, p.1ff.

2 - Einzig, P., Primitive Money: In its Ethnological, Historical and Economic Aspect, London, New York, Pergamon Press, 1966, p.192

3 - Grierson, P.J.H., The Silent Trade; A Contribution to the Early History of Human Intercourse, Edinburgh, William Green \& Sons, 1903.

4 - Geva, B., From Commodity to Currency in Ancient History: On Commerce, Tyranny, and the Modern Law of Money, Osgoode Hall Law Journal, Volume 25, Number 1, 1987, p.122: https://digitalcommons.osgoode.yorku.ca/ohlj/vol25/iss1/3/ 


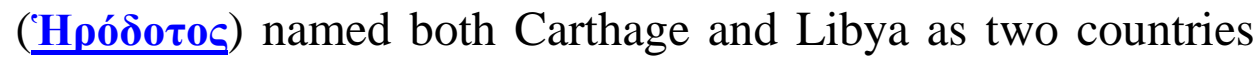
connected by silent trade.

That piece of information is clarified in the following passage:

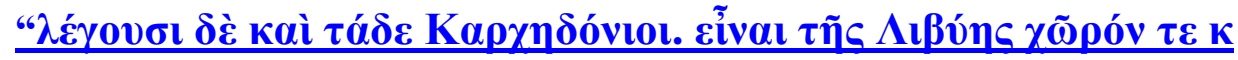

$\underline{a \grave{i}}$

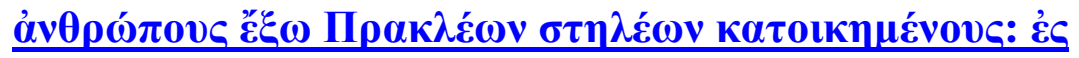

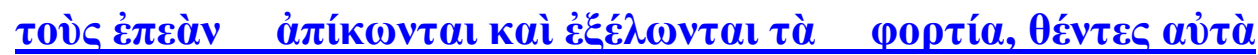

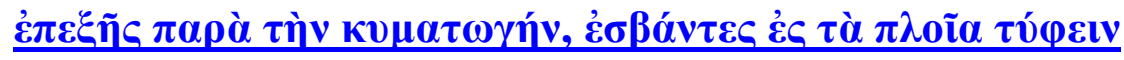

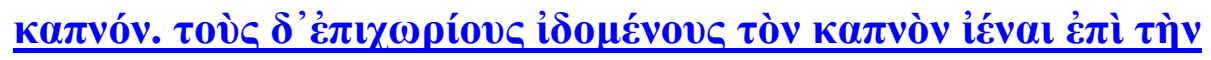

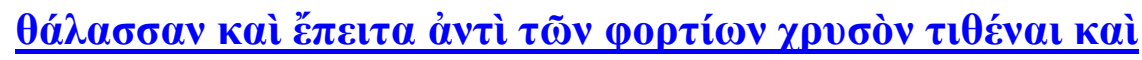

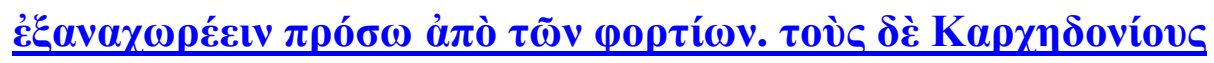

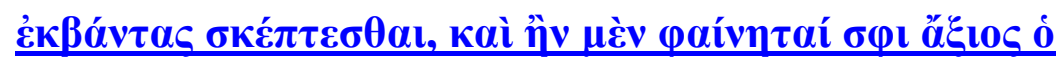

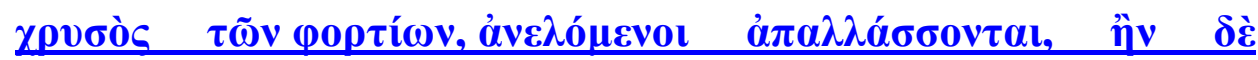

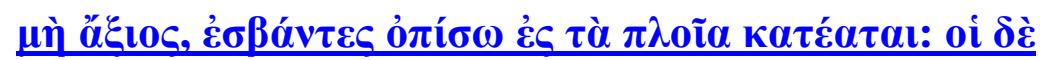

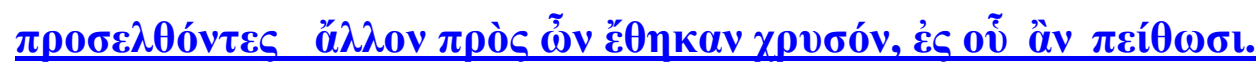

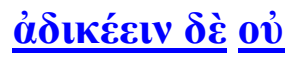

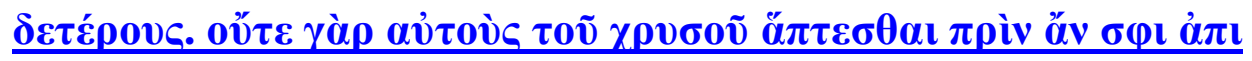
$\underline{\sigma \omega \theta \tilde{\eta}}$

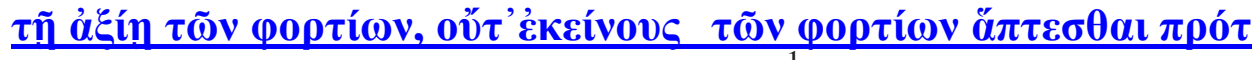

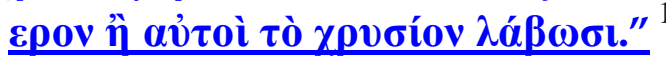

"The Carthaginians tell us that they trade with a race of men who live in a part of Libya beyond the Pillars of Herakles. On reaching this country, they unload their goods, arrange them tidily along the beach, and then, returning to their boats, raise a smoke. Seeing the smoke, the natives come down to the beach, place on the ground a

1 - Hdt. iv, 196. 
certain quantity of gold in exchange for the goods, and go off again to a distance. The Carthaginians then come ashore and take a look at the gold; and if they think it presents a fair price for their wares, they collect it and go away; if, on the other hand, it seems too little, they go back aboard and wait, and the natives come and add to the gold until they are satisfied. There is perfect honesty on both sides; the Carthaginians never touch the gold until it equals in value what they have offered for sale, and the natives never touch the goods until the gold has been taken away."1.

It is interesting to note that many ethnographers and travelers also report similar practices occurring in a variety of places in modern times ${ }^{2}$.

\section{Commodity Money}

Over time, impediments grew worse as the complexity of trade increased leading to a number of flaws. Eventually, the public started generating solutions to satisfy the growing need for an easy practice of exchange. This chaos led to the subsequent stage of bartering known as "Commodity Money" or "Primitive Money". Before going into detailed description for the role of this type of money, it is essential to pinpoint the difference between coins and money. A vast number of nonspecialists using the two terms interchangeably as they regard both of them as one yet; whatever was widely acceptable on paying for possessions was referred to as money at the time. It was the standard unit for exchange against which prices and

1 - Herodotus, "Histories 4.196". Livius.org. translated by: Aubrey de Selincourt.

2 - About these modern places, cf.: Sacks, D.H., "The Blessings of Exchange in the Making of the Early English Atlatic", in: Religion and Trade: Cross-Cultural Exchanges in World History, 1000-1900 ed. by: Trivellato, F., Halevi, L., and Antunes, C., USA, Oxford University Press, p.73.

3 - Geva, B., op. cit., pp.123-124; Seltman, C., Greek Coins, A History Of Metallic Currency And Coinage Down To The Fall of The Hellenistic Kingdoms, London, Methuen \& Co. LTD, 1965, p.5. 
debts were verified ${ }^{1}$. On the other hand the term coins denoted stamped pieces of metal with specific weights and designs which were authorized to be circulated as money for a permanent value. Hence, coins made of metal were categorized as a form of money ${ }^{2}$.

Back to "Commodity money", they were the opted goods recognized as a medium of exchange. They played roles in defining and comparing values aiming at specifying the worth of other merchandise ${ }^{3}$. In this manner, commodity money assessed in creating price lists which facilitated exchanging commodities of equal values against each other ${ }^{4}$. Assuredly, the items for purchase varied from one country to the other and its worth was affected by how essential it was for the people in that place. For example, cowrie shells acted as "Small Money" in both India and Africa ${ }^{5}$, while oxen in Greece served this purpose as well. They were all used as commodities habitually functioning and aiding people in their everyday life. The evidence of using oxen in Greece is sufficiently elaborated in Homeric epics ${ }^{6}$. At one instance, Odysseus's father, Laertes

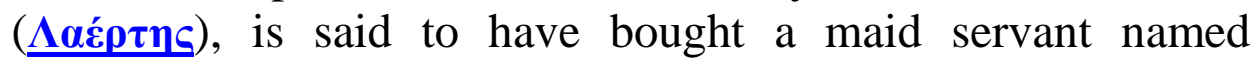

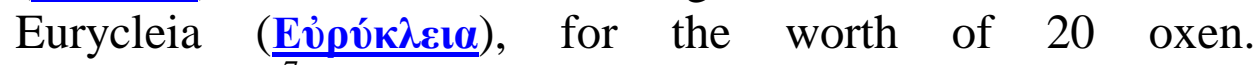

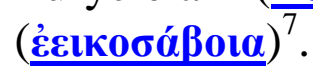

1 - Robertson, D.H., Money, Chicago, University of Chigaco Press, 1962, pp.2-3.

2 - Geva, B., op. cit., p.116.

3 - Roy, D., The Power of Money, India, New Delhi, 2011, p. 21.

${ }^{4}$-Bernholz, P. \& Vaubel, R., (Eds.), Explaining Monetary and Financial Innovation: A Historical Analysis (Financial and Monetary Policy Studies), 2014, p.154.

https://www.springer.com/la/book/9783319061085

5 - Yang, B., "The Rise and Fall of Cowrie Shells: The Asian Story", Journal of World History, Vol. 22, No. 1 (March 2011), p.2 ff.

6 -Bernholz, P. \& Vaubel, R., (Eds.), op. cit., p.156.

7 -Hom. Od.; I. 431. 
At another, Homer ('Ounpos) referred to the value of armor, gifts and females in units of cattle ${ }^{1}$.

However; it is much more interesting when Achilles (A $\chi \mathbf{\imath} \lambda \lambda \varepsilon v$ ś) contemplated whether valuing life could also be equated to certain amounts of valuable objects ${ }^{2}$, probably oxen regarded as one of such precious items.

Regrettably, over the ages, time proved again that "Commodity Money" had not satisfied the majority of the people as it was not practical and inconvenient ${ }^{3}$. Thus, people were in desperate need for a system that comprises small values which could be effortlessly accepted to facilitate their deals instead of the widespread bewilderment ${ }^{4}$.

\section{Metallic Money and the Evolution of Coins}

On that account, it was realized that metals could play an indispensable role in facilitating transactions. Using measurable metals disclosed another phase that different societies have witnessed on the passage of trying to overcome the passive practices of commodity money ${ }^{5}$. Compared to oxen, weighed valuable metals were more favorable among the population. Metals were definitely easily stored, more durable, lighter and portable. Chiefly, gold and silver, not any base metal, were molded in the form of rings and spirals as people were fond of keeping these most valued possessions on their arms and legs aiming at protecting their assets and using them

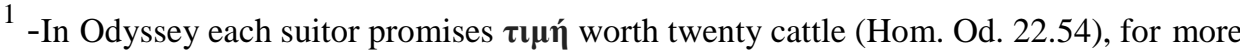
examples see: Walter Donlan, "The Unequal Exchange between Glaucus and Diomedes in Light of the Homeric Gift Economy", Phoenix, Vol. 43, No. 1 (Spring, 1989), pp. 1 15; Reden, S.V, "Money, Law and Exchange: Coinage in the Greek Polis", The Journal of Hellenic Studies, Vol. 117 (1997), pp. 154-176.

2 - Hom. II. 9.632-8.

3 - Geva, B., op. cit., p.128; Note the comparison between commodity money and metals, hence the preference of metals, p.7.

4 - Geva, B., op. cit., p.128.

5 - Michell, H., The Economics of Ancient Greece, Cambridge, Cambridge University Press, 1940, p. 328.
} 
in exchange when needed. The divisibility of metal into any desired size was required. Definitely, they wouldn't accept to convert their ox to beef to satisfy their need for small possessions. Opposed to this, people could easily chop off pieces from any metal to obtain the desirable amount wanted for their transactions. Metal, on the other hand, could be carved and given a uniformed size which could be equivalent to specific values. That is how the usage of metal spread universally ${ }^{1}$.

Unfortunately, metal money, which is termed "Quasicoins" by some recent numismatists ${ }^{2}$, was easily counterfeited ${ }^{3}$. Inevitably, the worth of such money decreased as it was made of base metal which made people hesitant to utilize safely. This paved the way to true coinage which overcame the drawbacks of metal money. The blemish of such kind of metallic currency

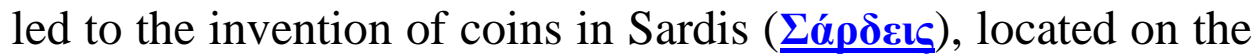
west coast of present-day Turkey, the capital of Lydia $(\underline{\boldsymbol{\Lambda} \boldsymbol{v} \boldsymbol{\delta} \mathbf{i} \boldsymbol{\alpha}})^{4}$, during the seventh century ${ }^{5}$. The Lydians stamped small

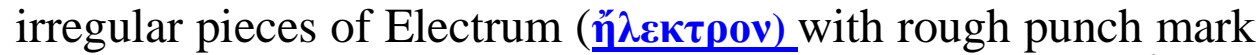
assuring the accuracy of weight, fineness, or both of them ${ }^{6}$. The The usage of Electrum was preferable to the Lydians as it was the most plenteous valuable metal in the region. It was

1 - Geva, B., op. cit., pp.128-129.

2 - Davis, G. A History of Money From Ancient Times to the Present Day, Cardiff, University of Wales, 2002, p.62.

3. Lynott, W. J. 'Money: How to Make the Most of What You've Got, USA, I Universe.com, 2000, p.4.

${ }^{4}$ - It is worth to note that there are some ancient writers referred to a mythological origin

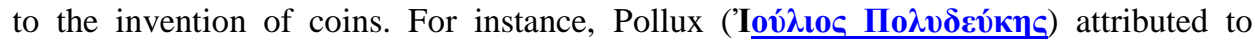

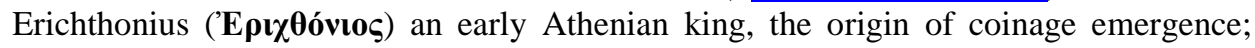
Poll., Onom., 9.83.

5 - Presenting an accurate date for the invention of coins is a troublesome. It is not still confirmed whether electrum coinage began in the first or second half of the seventh century. However the arguments for the later dating are stronger, cf:

Cook, R.M., "Ionia and Greece in the Eighth and Seventh Centuries B. C.", The Journal of Hellenic Studies, Vol. 66 (1946), p. 91.

6 - Beaudreau, B.C., Making Markets and Making Money: Strategy and Monetary Exchange, New York, I universe, Inc, 2004, p.15. 


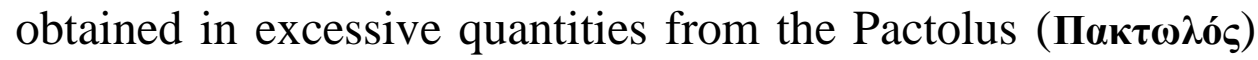
and other Lydian rivers of Mount Tmolus ( $\underline{\mu} \tilde{\tilde{\omega}} \boldsymbol{\lambda} \mathbf{0}$ ) watershed ${ }^{1}$. According to Herodotus, this alloy of gold and

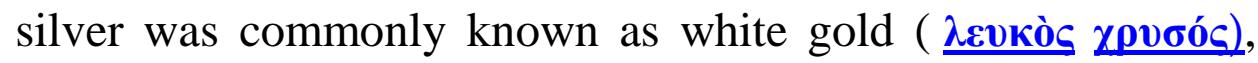
because of its pale yellow color. The historian also stated that:

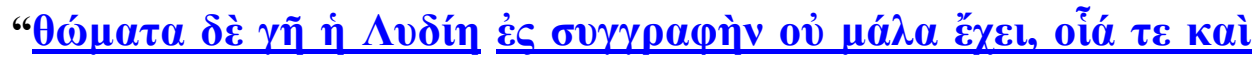

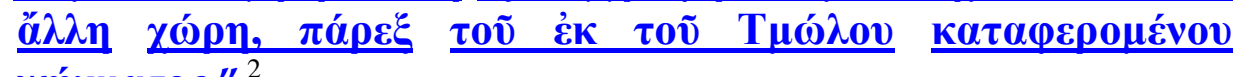

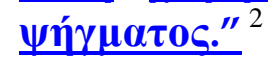

\section{"There are not in Lydia many marvelous things for me to tell of, if it be compared with other countries, except the gold dust that comes down from Tmolus."}

It is worth mentioning that the first electrum coins had no regular shape. The circular shape was never used at the time but rather strange shapes like flat nuggets or dense kidney beans. Nevertheless, these pieces enabled transferring pieces of coins freely, which led to speeding up trade ${ }^{4}$.The idea of striking coins rapidly spread to the Greeks of the islands and the mainland. Soon, at the closure of the sixth century, using coins became common practice in most of the countries which were ruled by the Greeks 5 .

1 - There is a myth relating that the river attained its electrum, when King Midas of the neighboring Phrygia washed in it to get rid of his golden touch, which had twisted even his food into gold, Ov. Met. xi. 90.

2 - Hdt. 1.93 .

3 - The Text of Herodotus on Lacus Curtius, http://penelope.uchicago.edu/Thayer/E/Roman/Texts/Herodotus/1B*.html

4 - Geva, B., op. cit., p.130; Although both Aristotle (Nicomachean Ethics, 1133a 1720) and Herodotus (1.94) admitted that coins were first minted to assist the progress and retail trade, yet some modern scholars have different view. Laum, as an example, believed in the religion origin of coinage: Laum, B., Heiliges Geld. Eine historische Untersuchung über den sakralen Ursprung des Geldes, Tübingen: Mohr, 1924. For further discussion and point of views, see: Bernholz, P. \& Vaubel, R., (Eds.), Explaining Monetary and Financial Innovation.

5 - Howgego, C., Ancient History from Coins, Routledge, Library of Congress, 1995, p.6. 


\section{Barter Phases in Egypt}

Moving on to Egypt, obviously, the Egyptians resembled the other civilizations in passing through different phases of barter. Yet, they did not use coins as widely as other civilizations. Initially, they were more comfortable in depending on the primitive barter system. However, after discovering the drawbacks of this system, they preferred using commodity money. Doubtlessly, grain being one of the principle sources of wealth, that is why the Egyptians used grain as the top most standard commodity for exchange ${ }^{1}$, but without disregarding the primitive barter system totally as it was still used among individuals through Ptolemaic era ${ }^{2}$.

Following the steps of the other nations, the Egyptian society started adopting metals as early as old kingdom, in specifying the prices of services and all kinds of chattels. As a matter of fact, gold, silver and copper had a dual function: first, they were used in sundry commercial relations. Second, they were operated locally as a measure of value rather than an actual payment. Deben, kite and Shaty were the terms applied for expressing various Egyptian prices ${ }^{3}$. Shaping gold and silver in the form of rings was more convenient for interchanging precious metals. These rings were often opened and linked in the shape of chains. Tal El-Amarna hoard is considered to be an obvious attestation for the usage of silver rings during the $14^{\text {th }}$ century $\mathrm{BCE}$. The hoard comprises two gold ingots in addition to bars, clusters, coils and rings of silver that were used as a pre-monetary medium of exchange (pl.ii,

1 - Einzig, P., op. cit, p.202.

2 - Samuel, AE., The Money Economy and the Ptolemaic Peasantry, The Bulletin of the American Society of Papyrologists, Vol. 21, No. 1/4 (1984), p.200.

3 - Balmuth, M.S., "The Critical Moment: The Transition from Currency to Coinage in the Eastern Mediterranean”, World Archaeology, Vol. 6, No. 3, Currency (Feb., 1975), p.294. for the value of each of: Deben, Kite, Shaity, cf. Robens, E., Jayaweera, S.A. \& Kiefer, S., Balances: Instruments, Manufacturers, History, Heidelberg, London, Springer, 2014, p.44 ff. 
fig. 1$)^{1}$. The walls of some tombs are adorned with pictorial records of such ring form. The Theban tomb of Rekhmire, Vizier of Thutmosis III $\left(15^{\text {th }} \text { century BCE }\right)^{2}$, as an example, displays the weighing of gold and silver rings which operated as ingots for the pharaohs (pl.ii, fig.2) ${ }^{3}$. Nonetheless, for ages, silver appeared to be the most preferable metal for payments in Egypt. Subsequently, any reader would wonder and ask: from where the Egyptians got all this amount of silver in spite of the fact that there were no indigenous silver mines in the Egyptian land ${ }^{4}$ ? Beyond doubt, Greece was the nearest place where there was an abundance of silver that could be easily transferred to Egypt. Greek Silver was exchanged for the Egyptian grain which was the pivotal Egyptian item of trade at that period ${ }^{5}$. Tracking the reciprocal commercialized interactions between Greece and Egypt, throughout the ages, reveals its incessant binding ties as the following lines will elucidate.

Theban tombs, Rekhmire, show depictions of Cretan ambassadors carrying metal vases to the royal court indicating the transfer of silver from the Minoan kingdom to Egypt (pl.iii, fig. 3$)^{6}$. As a divergent, upon the collapse of Crete, there was

1- Muhs, B., The Ancient Egyptian Economy: 3000-30 BCE, Cambridge, Cambridge University Press, 2016, p.115.

2 -Note that the Vizer was the most potent character, after Pharaoh, in the state. For more information see: White, J. E. M. Ancient Egypt: Its Culture and History, New York, Dover Publications, 2013, p.47; for more details about the responsibilities of the Vizier, cf.

Boorn, Van den, "On the Date of "The Duties of the Vizier", Orientalia, Nova Series, Vol. 51, No. 3 (1982), pp. 369-381.

3 - Einzig, P., op. cit, p.197; Schaps, D., The Invention of Coinage and the Monetization of Ancient Greece, USA, University of Michigan, p. 50.

4 - Gale, N. H. \& Stos-Gale, Z. A., “Ancient Egyptian Silver", The Journal of Egyptian Archaeology, Vol. 67 (1981), pp. 103-115.

5 - Milne, J.G., "Trade between Greece and Egypt before Alexander the Great", The Journal of Egyptian Archaeology, Vol. 25, No. 2 (Dec., 1939), pp. 178; Sutherland, C. H. V., "Corn and Coin: A Note on Greek Commercial Monopolies", The American Journal of Philology, Vol. 64, No. 2 (1943), p.143.

6 - Spier, J., Potts, T.F., \& Cole, S.E, Beyond the Nile: Egypt and the Classical World, Los Angeles, Getty Publications, 2018, p.27. 
dread of the lack of security in communication which was a hazard to trade. Though Egyptian articles were transported to Greece during the Mycenaean age (c. 1600-1100 BCE), yet there is no crucial evidence for direct overseas trade between the two civilizations ${ }^{1}$. The Elimination of Mycenaean Greece was a turning point event that took place around $1100 \mathrm{BCE}$ by

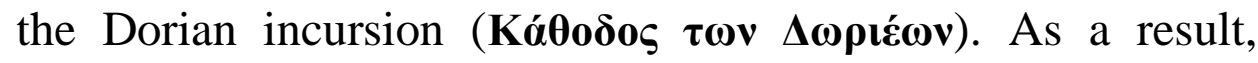
many Mycenaean refugees migrated to the western Asiatic coast where they found their own communities ${ }^{2}$. Thus, they renewed trading with Egypt on account of their need to corn ${ }^{3}$.

A transitional point occurred upon setting-up the Greek

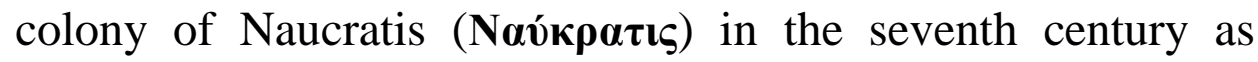
commanded by Amasis around 565 BCE. Thus, a new significant trading port flourished ${ }^{4}$. Indeed, Naucratis was a vibrant bridge that permitted the infusion of a considerable amount of electrum, but, a sufficient amount of silver ${ }^{5}$. It is worth mentioning that the Asiatic cities participated in founding Naucratis provided Egypt, at the outset, with electrum in exchange for corn. Actually, the Egyptian museum keeps ingots of electrum in addition to some electrum coins which present an indication for such business relations. Knowing that silver would be favored by the Egyptians, the Asian tribes, mainly Chians and Ionians, managed to bring enough amounts

1 - Milne, J.G., "Trade between Greece and Egypt before Alexander the Great”, p.179.

2 - Stiebing, W.H., "The End of the Mycenean Age", The Biblical Archaeologist, Vol. 43, No. 1 (Winter, 1980), p. 7.

3 - Milne, J.G., "Trade between Greece and Egypt before Alexander the Great", p.179.

${ }^{4}$ - For the relationship between Amasis and the Greeks who settled

Egypt, cf. Cook, R.M., "Amasis and the Greeks in Egypt", The Journal of Hellenic Studies, Vol. 57, Part 2 (1937), pp. 227-237.

5 - Milne, J.G., "Trade between Greece and Egypt before Alexander the Great", p.179. 


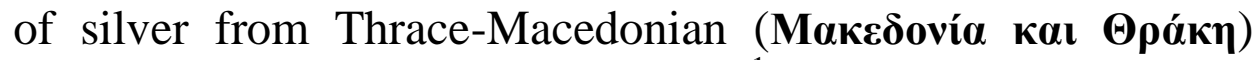
region to fulfill their deals with Egypt ${ }^{1}$.

A paramount mutation emerged when Athens monopolized silver trade in Egypt starting from about the end of the sixth to the middle of the fourth century. As a result, Egyptian hoards after c. 480 BCE denoted massive quantities

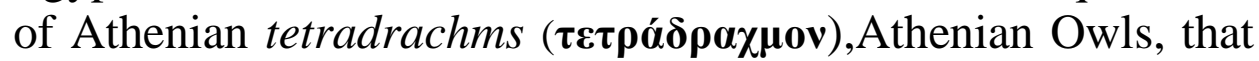
were constantly circulated in Egypt, owing to their consistency in weight and metal finesse ${ }^{2}$. The growing need for this denomination motivated the authorities in Egypt to strike their own imitative type ${ }^{3}$, possibly dating from the end of the late fifth century ${ }^{4}$. Indeed, Egypt practiced such mintage for two main causes: first, the Athenian production declined remarkably by the end of the Peloponnesian War

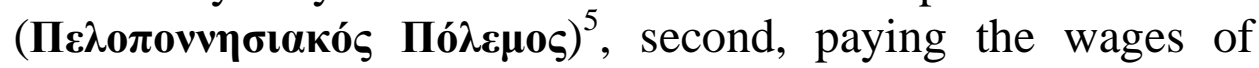
Greek mercenaries was an urgent requirement to banish the Persian occupation ${ }^{6}$. On account of the same former purpose, the Egyptian kings of the $29^{\text {th }}$ and $30^{\text {th }}$ dynasties started to produce coins locally. The first step was under taken in the

1 - Sutherland, C. H. V., "Corn and Coin: A Note on Greek Commercial Monopolies", p.143; that is why $30 \%$ of the total Archaic coin hoards originate from this area (ThraceMacedonian) cf. Roebuck, C., "The Grain Trade between Greece and Egypt", Classical Philology, Vol. 45, No. 4 (Oct., 1950), p. 237.

2 - Mavrogordato, J., "Was There A Pre-Macedonian Mint in Egypt?", The Numismatic Chronicle and Journal of the Royal Numismatic Society, Fourth Series, Vol. 8, 1908, p.202

3 -The Athenian coins dies found in Egypt clearly prove Egypto-Athenian imitations, cf. Jongkees, J. H., "Athenian Coin Dies from Egypt", The Numismatic Chronicle and Journal of the Royal Numismatic Society, Sixth Series, Vol. 10, No. 39/40 (1950), pp. 298-301.

4 - Both authentic and imitative issues were circulating side by side till the fourth century, whereas the imitations were more preponderant; cf. Muhs, B., op. cit., p.191; van Alfen, P.G., "Herodotus' "Aryandic" Silver and Bullion Use in Persian-Period Egypt", American Journal of Numismatics, Vol. 16/17, 2004-05, p.13.

5 - Kroll, J. H., "The reminting of Athenian silver coinage, 353 B.C." Hesperia 80: p.241.

6 - Milne, J.G., "The Beni Hasan Coin-Hoard", The Journal of Egyptian Archaeology, Vol. 19, No. 3/4, 1933, p.120. 
middle of the fourth century by the Egyptian king Teos (362-

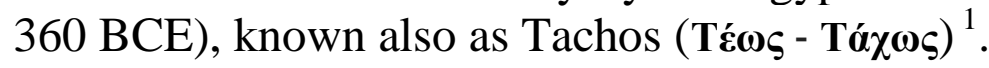

\section{Unpublished Ingots}

Indisputably, the previous economic changes had left its impact on the excavated silver in the Egyptian soil. Enormous quantities of different forms had been discovered on a large scale from Delta to Aswan ${ }^{2}$. Before elaborating, we should first tackle the Egyptian coin hoards, both archaic and classical, since they shed light on pertinent information about the two ingots under study. As a matter of fact, the overall hoards are categorized into two main groups:

A) Hoards without coins:

Three archaeological sites, Mit Rahineh (ancient Memphis), Samanoud and Tel-Athrib (both located in Delta), demonstrate that the three hoards excavated there, are composed entirely of unminted silver pieces without any single piece of coin. It is presumed that these hoards were buried before the last quarter of the sixth century which marks the surplus of the Greek coins in Egypt. Lumps, ingots, whether in the form of complete round cake or dumps, amulets, rings and Hacksilber are the only silver components of these hoards ${ }^{3}$. It is to be noted that the German numismatists created this term "Hacksilber" (means irregularly cut silver) referring to the fragmented, twisted and bent silver items which constitute an entire or part of a hoard ${ }^{4}$.

\footnotetext{
${ }^{1}$-He was the first Egyptian king whose name was abbreviated in Greek letters on the reverse of a gold stater: For a brief overview of Egyptian coin types, cf. Curtis, J. W., "Coinage of Pharaonic Egypt", The Journal of Egyptian Archaeology, Vol. 43 (Dec., 1957), pp. 71-76.

2 -For a general review cf. Noe, S.P., “A bibliography of Greek coin hoards", Numismatic Notes and Monographs, No. 25, 1925, pp.1-277.

3 - Kroll, J., "A Small Find of Silver Bullion From Egypt", American Journal of Numismatics (1989-), Vol. 13 (2001), pp. 3-4.

4 - Frey, A.R., "A Dictionary of Numismatic Names: Their Official and Popular Designations", American Journal of Numismatics (1897-1924), Vol. 50 (1916), S.V. Hacksilber.
} 
B) Mixed Hoards:

Several excavations and donations reveal that they are fifteen hoards, dated from the late archaic period (c.500 BCE), unearthed from both Delta (such as: Demanhur, Sakha, Benha el-Asl Naucratis and Zagazig) as well as the middle Egypt (Asyut-Beni-Hassan). As indicated from their appellation they comprised both coins from several Greek city-states along with ingots and Hacksilber ${ }^{1}$.

Focusing on the two ingots under study, it is unfortunately that there is no recorded data in the museum to determine whether the they were buried separately or with many other pieces as a hoard. Moreover, we have no definite information about their find spot. The gold piece is a fragmentary rectangular slab $(42 \mathrm{gm}-30 \times 26 \mathrm{~mm}$, diameter is measured at the widest point), preserved under special register number 817 . It could be deduced that this gold ingot, which is the solitary piece acquired by the museum, is not only rare but it is also exceptional if compared to what was found previously in different hoards for the subsequent two reasons: (1) A deliberate review to each hoard, whether without coins or mixed, will clarify that silver rather than gold is the prevailing metal for ingots. Tell El-Mashkuta (c. 400-330 BCE, near AbuSeir) is the only mixed hoard that contains gold ingots ${ }^{2}$.

1 - Gilter, H., "A Hacksilber and Cut Athenian Tetradrachm Hoard from the Environs of Samaria: Late Fourth Century BCE", Israel Numismatic Research 1 (2006), pp.6-7; Kroll, J., "A Small Find of Silver Bullion From Egypt",pp.4-6;Thompson, M., Mørkholm, O., and Kraay, C.M., An Inventory of Greek Coin Hoards, New York: Publ. for the International Numismatic Commission by the American Numismatic Society, 1973, p.225 ff; van Alfen, P.G., "A New Athenian "Owl" and Bullion Hoard from the Near East”, American Journal of Numismatics (1989), Vol. 16/17 (2004-05), pp. 47-61.

2 - This is a very big hoard of about 6,000 pieces of tetradrachms, see some pieces via this article: Robinson, E. S. G., "The Tell El-Mashkuta Hoard of Athenian Tetradrachms", The Numismatic Chronicle and Journal of the Royal Numismatic Society, Sixth Series, Vol. 7, No. 3/4 (1947), pp. 115-121. For the reference to the gold ingots within the hoard, cf. Gilter, H., op. cit., p.7. 
However, there is no precise recording for the actual number of such ingots ${ }^{1}$.

(2) The square and rectangular ingots were utterly a western Greek phenomenon ${ }^{2}$, whilst round cake ingots are the predominate form of the Egyptian hoards. Contemporary rectangular specimens are found through "A Greek Archaic Silver Hoard from Selinus" which contained three rectangular fragments; one has graffiti on one of its sides, while the other two are stamped on one side only ${ }^{3}$. Accordingly, we could infer that such rectangular gold ingots were exceptionally imported to Egypt through trade in small numbers for minor, every-day, transactions. Furthermore, it is apparent that these ingots were melted as soon as the exchange process was successfully accomplished to be used in manufacturing different items. We might say that the piece under study is a strong evidence for this case.

As for the silver piece $(64 \mathrm{gm}-37 \mathrm{~mm})$, it is a complete quasi-round cake ingot, with some scratches from both sides, preserved in the museum under special register number 808. It is noticeable that the size of this piece is quiet larger if compared with many other pieces from different Egyptian hoards. To cite an instance, almost all round ingots from Benha El-Asl and the Delta hoards are nearly the same size as the Greek silver tetradrachm (c. $25 \mathrm{~mm})^{4}$. In contrast, our silver

1 - Thompson, M., Mørkholm, O., and Kraay, C.M., op.cit, no.1649.

2 - It is a remarkable note that a number of these ingots bear archaic Greek dedicatory inscriptions in some sanctuaries, cf. Kroll, J., "The Monetary Use of Weighed Bullion in Archaic Greece," in W Harris (ed.), "The Monetary Systems of the Greeks and Romans", Oxford, Oxford University Press, Chapter 1, 2008, p.26.

3 - Arnold-Biucchi, C. Beer-Tobey, L. \& Waggoner, N., “A Greek Archaic Silver Hoard from Selinus", Museum Notes ,American Numismatic Society, Vol. 33, 1988, pp. 26-28.

4 - Kroll, J., "A Small Find of Silver Bullion From Egypt”, pp.8-9.=

$=$ It is to be mentioned that Van Alfen published the heavier silver ingot ever excavated from Egypt with $14622.98 \mathrm{gm}$. It is incomparable to any other ingot whether from Levantine or Western Greek hoards; "Herodotus' "Aryandic" Silver and Bullion Use in Persian-Period Egypt", p.11. 
ingot resembles in shape most pieces in other hoards. The plano-convex and round cake is the predominant ingot shape not only in Egypt but also in the Levant too ${ }^{1}$.

\section{Debate about the function of ingots}

Scholars are not in broad agreement about the principle function of Egyptian hoards in general and ingots in particular. The first scholars regarded these hoards as remains of either an unknown mint $^{2}$, or a jeweler's workshop ${ }^{3}$. Hence, these scholars categorized them as "Silversmiths". To clarify this point, when Petrie discovered a hoard of 15 silver coins at Naukratis, he assumed his findings to be part of a silversmith's stock in trade ${ }^{4}$. As opposed to this view, Dressel and Regling affirmed the presence of a monetary convention system ${ }^{5}$. They believed that the frequent occurrence of bars and ingots, side by side, with coins proves the monetary nature of these findings. Many researchers were in agreement with Dressel and Regling's opinion, hence, termed them as "Bullion Hoards" It was mainly through the papyri documents, along with the hoards, that these researchers identified a clear monetary purpose.

Beginning with papyri, it is easy to perceive that in the second half of the seventh century, Egypt began to receive an unparalleled inflow of foreigners from the Aegean and the

1 - Kroll, J., "A Small Find of Silver Bullion From Egypt”, p.8.

2 - Dutilh, E. D. J., "Vestiges d'atelier monétaire", Journal Internationale d' Archeologie Numismatique, No.2, pp.283-288.

3 - Brugsch, E., "Sur deux trouvailles de culots d'argent provenant de Mit-Rahineh", Annales du service des antiquités de l' Egypt, 1906, No.7, p.16.

4 - Head, B.V., "Coins Discovered on the site of Naukratis", The Numismatic Chronicle and Journal of the Numismatic Society, Third Series, Vol. 6, 1886, p.4 ff.

5 - Dressel, H. and K. Regling, "Zwei ägyptische Funde altgriechischer Silbermünzen. Zeitschrift für Numismatik, No. 37, pp.1-138.

6 - Milne, J.G., "The Beni Hasan Coin-Hoard", p.121; Roebuck, C., "The Grain Trade between Greece and Egypt, p.237; van Alfen, P.G., "Herodotus' "Aryandic" Silver and Bullion Use in Persian-Period Egypt", pp.7-8. 
Levant, who came as vendors and mercenaries. Henceforth, constituted their, distinctive, cultural groups. Most of these immigrants, for instance the Jewish garrison settled in the

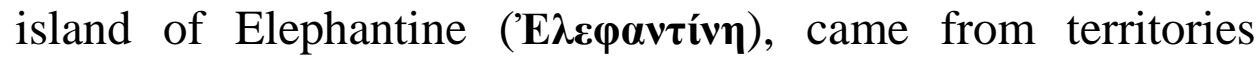
where weighed silver had long been used as currency. Appropriately, these communities heightened the prevalence of dealing with silver in the monetary context in Egypt ${ }^{1}$. The wellknown corpus of Elephantine papyri, written in Aramaic Language, show that lots of matters, as contracts of marriage, receipts of payment and the like, were depending mainly upon weights of silver ${ }^{2}$. It is obvious that the community utilized silver as a currency system.

On pointing to the evidences from hoards, the clipped pieces of coins are a logical and visual sign that they were treated mainly as bullion. The coins were deliberately clipped into lumpy fractions, halves, quarters or even tenths, of their original shapes in order to form segments ready to be weighed upon monetary dealings. Here, it is worth mentioning that the Egyptian museum comprises clipped pieces in which some of them were published by Abdel Mohsen El-Khachab (pl. iii, fig. 4$)^{3}$.

"Aryandic Silver" is another evidence, related to the hoards, that could be deduced from the fourth book of Herodotus which manifests the employment of ingots as a monetary medium of exchange. Herodotus related the following story:

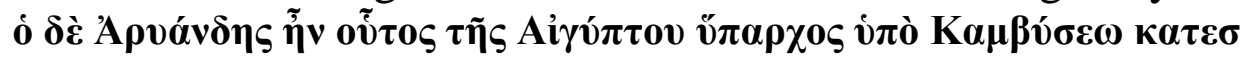
$\tau \varepsilon \dot{\omega} \varsigma$,

1 - Kroll, J., "A Small Find of Silver Bullion From Egypt”, pp.12-13.

2. Van Alfen, P.G., "Herodotus' "Aryandic" Silver and Bullion Use in Persian-Period Egypt", American Journal of Numismatics, Vol. 16/17, 2004-05, pp. 22-24; For contract marriage, as an example, cf. Kraeling, E. G., The Brooklyn Museum Aramaic papyri : new documents of the fifth century B.C. from the Jewish colony at Elephantine. New Haven, Yale University Press, 1953, Papyrus 7, lines: 24-26.

3 - El-Khachab, M.A.M., Coins and Gems, Reprinted from: Introduction to Egyptian Archaeology: with Special Reference to the Egyptian Museum, Cairo, General Organization for Government Printing Offices, 1988, pl. L, Fig.3 (a,a,b). 
ò yò

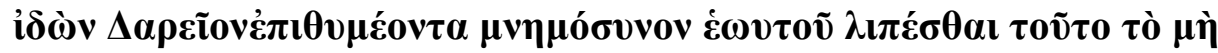

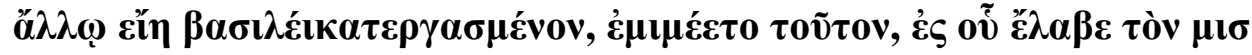
өóv.

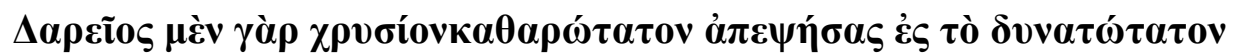

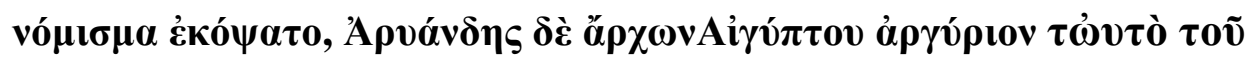

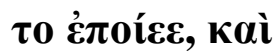

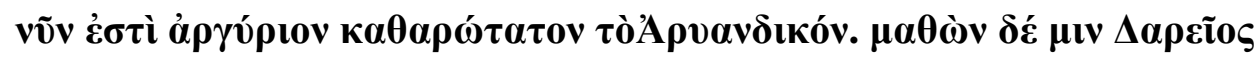

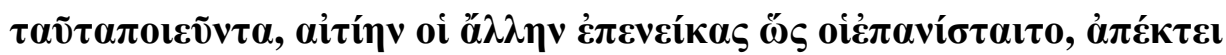
ve." 1

"This Aryandes had been appointed viceroy of Egypt by Cambyses; at a later day, he was put to death for making himself equal to Darius. For, learning and seeing that Darius desired to leave a memorial of himself such as no king ever had, Aryandes imitated him, until he got his reward; for Darius had coined money out of gold refined to an extreme purity, and Aryandes, then ruling Egypt, made a similar silver coinage; and now there is no silver money so pure as is the Aryandic. But when Darius heard that Aryandes was doing so, he put him to death, not on this charge but as a rebel.",

As mentioned above, Herodotus stated that after Darius had purified gold to struck coins, Aryandes attempted to immortalize himself too, by purifying silver when he became satrap in Egypt. Aryandes lost his life because of this act. He was put to death as Darius accused him of conspiring against

1 - Hdt. iv. 166

2 - Perseus Under Philologic, (Hdt., 4.166.1-2).

http://perseus.uchicago.edu/perseuscgi/citequery3.pl?dbname=GreekText s\&getid=1\&query=Hdt.\%204.165.2 
him. Several specialists with different perspectives commented on Herodotus' passage. However, no one was capable of having a clear judgment whether the "Aryandic Silver" was an actual coin or not. Thus, what Herodotus has mentioned in that passage is still a matter of conjecture Nevertheless, Milne was one of the scholars who attempted to rationalize the reality about this piece. He alleged in 1938 that The Aryandic Silver was simply the ordinary Persian coin denomination known as "Sigloi", contrary to Van Alfen in 2005 who argued that Aryandic Silver is not coinage but exceptionally pure silver bullion ${ }^{2}$.

To sum up, the above mentioned evidences, in the light of papyri and hoards, prove that ingots had been used constantly in monetary dealings. Though, we shouldn't ignore totally that ingots and coins were also melted occasionally to be used in manufacturing some items by the silversmiths. Thus, the researcher suggests both functions for ingots; however the monetary usage was more predominant. In addition, studying different Egyptian hoards proved that the gold piece, under study, is a very rare one that was not excavated before through any previous hoard, at least according to the comparable published gold ingots.

1 - Milne, J.G., "The Silver of Aryandes", The Journal of Egyptian Archaeology, Vol. 24, No. 2, 1938, pp. 245-246.

2 - Van Alfen, P.G., "Herodotus' "Aryandic" Silver and Bullion Use in Persian-Period Egypt", pp.7-8. 


\section{Greek and Latin sources}

$\begin{array}{ll}\text { Aristotle (Arist.) } & \text { Ethica Nicomachea } \\ \text { Herodotus (Hdt.) } & \text { Historiae } \\ \text { Homerus (Hom.) } & \text {-Iliad } \\ & \text {-Odyssey } \\ \text { Ovid (Ov.) } & \text { Metamorphoses } \\ \text { Pollux (Poll.) } & \text { Onomasticon }\end{array}$

It should be noted that quotations are based on the two following academic sites:

http://www.perseus.tufts.edu/hopper/

http://penelope.uchicago.edu/Thayer/E/Roman/Texts/home.html

\section{References}

Arnold-Biucchi, C. Beer-Tobey, L. \& Waggoner, N., "A Greek Archaic Silver Hoard from Selinus", Museum Notes, American Numismatic Society, Vol. 33, 1988, pp. 1-35.

https://www.springer.com/la/book/9783319061085

Balmuth, M.S., "The Critical Moment: The Transition from Currency to Coinage in the Eastern Mediterranean”, World Archaeology, Vol. 6, No. 3, Currency (Feb., 1975), pp. 293-298.

Beaudreau, B.C., Making Markets and Making Money: Strategy and Monetary Exchange, New York, I universe, Inc, 2004.

Bernholz, P. \& Vaubel, R., (Eds.), Explaining Monetary and Financial Innovation: A Historical Analysis (Financial and Monetary Policy Studies), 2014,

Boorn, Van den, "On the Date of "The Duties of the Vizier", Orientalia, Nova Series, Vol. 51, No. 3 (1982), pp. 369-381. 
Brugsch, E., "Sur deux trouvailles de culots d'argent provenant de MitRahineh", Annales du service des antiquités de l' Egypt, 1906, No.7, p.16.

Colburn, H.P., "The Role of Coinage in the Political Economy of Fourth Century Egypt", in: Ptolemy I and the Transformation of Egypt, 404282 BCE, ed. by: Mckechnie, P. \& Cromwell, Boston, J.,Brill, 2018, pp.70-119.

Cook, R.M., "Amasis and the Greeks in Egypt", The Journal of Hellenic Studies, Vol. 57, Part 2 (1937), pp. 227-237.

—, "Ionia and Greece in the Eighth and Seventh Centuries B. C.”, The Journal of Hellenic Studies, Vol. 66 (1946), pp. 67-98.

Curtis, J. W., "Coinage of Pharaonic Egypt", The Journal of Egyptian Archaeology, Vol. 43 (Dec., 1957), pp. 71-76.

Davis, G., A History of Money From Ancient Times to the Present Day, Cardiff, University of Wales, 2002, p.62.

Dressel, H. and K. Regling, "Zwei ägyptische Funde altgriechischer Silbermünzen. Zeitschrift für Numismatik, No. 37, pp.1-138.

Dutilh, E. D. J., "Vestiges d'atelier monétaire", Journal Internationale d' Archeologie Numismatique, No.2, pp.283-288.

Einzig, P., Primitive Money: In its Ethnological, Historical and Economic Aspect, London, New York, Pergamon Press, 1966.

El-Khachab, M.A.M., Coins and Gems, Reprinted from: Introduction to Egyptian Archaeology: with Special Reference to the Egyptian Museum, Cairo, General Organization for Government Printing Offices, 1988. 
Frey, A.R., "A Dictionary of Numismatic Names: Their Official and Popular Designations", American Journal of Numismatics (18971924), Vol. 50 (1916), S.V. Hacksilber.

Gale, N. H. \& Stos-Gale, Z. A., "Ancient Egyptian Silver", The Journal of Egyptian Archaeology, Vol. 67 (1981), pp. 103-115.

Geva, B., From Commodity to Currency in Ancient History: On Commerce, Tyranny, and the Modern Law of Money, Osgoode Hall Law Journal, Volume 25, Number 1,1987, https://digitalcommons.osgo-ode.yorku.ca/ohlj/vol25/iss1/3/

Gilter, H., "A Hacksilber and Cut Athenian Tetradrachm Hoard from the Environs of Samaria: Late Fourth Century BCE”, Israel Numismatic Research 1 (2006), pp. 5-14.

Greenwell, W. \& Greenwell, C., "On a Find of Archaic Greek Coins in Egypt", The Numismatic Chronicle and Journal of the Numismatic Society, Third Series, Vol. 10, 1890, pp. 1-12.

Grierson, P.J.H., The Silent Trade; A Contribution to the Early History of Human Intercourse, Edinburgh, William Green \& Sons, 1903.

Head, B.V., "Coins Discovered on the site of Naukratis", The Numismatic Chronicle and Journal of the Numismatic Society, Third Series, Vol. 6, 1886, pp. 1-18.

Howgego, C., Ancient History from Coins, Routledge, Library of Congress, 1995.

Jongkees, J. H., "Athenian Coin Dies from Egypt", The Numismatic Chronicle and Journal of the Royal Numismatic Society, Sixth Series, Vol. 10, No. 39/40, 1950, pp. 298-301. 
Kraeling, E. G., The Brooklyn Museum Aramaic papyri : new documents of the fifth century B.C. from the Jewish colony at Elephantine. New Haven, Yale University Press, 1953.

Kroll, J., “A Small Find of Silver Bullion From Egypt”, American Journal of Numismatics (1989-), Vol. 13 (2001), pp. 1-20. , "The Monetary Use of Weighed Bullion in Archaic Greece," in W Harris (ed.), "The Monetary Systems of the Greeks and Romans", Oxford, Oxford University Press, Chapter 1, 2008, pp.12-37. ,"The Reminting of Athenian silver coinage, 353 B.C." Hesperia 80, 2011, pp. 229-259.

Laum, B., Heiliges Geld. Eine historische Untersuchung über den sakralen Ursprung des Geldes, Tübingen: Mohr, 1924.

Lynott , W. J., Money: How to Make the Most of What You've Got, USA, I Universe.com, 2000, p.4.

Mavrogordato, J., "Was There A Pre-Macedonian Mint in Egypt?", The Numismatic Chronicle and Journal of the Royal Numismatic Society, Fourth Series, Vol. 8, 1908, pp. 197-207.

Michell, H., The Economics of Ancient Greece, Cambridge, Cambridge University Press, 1940.

Milne, J.G., "A Hoard of Coins from Egypt of the Fourth Century B. C.", Revue Archéologique, Quatrième Série, 1905, pp. 257-261. , "The Beni Hasan Coin-Hoard", The Journal of Egyptian Archaeology, Vol. 19, No. 3/4, 1933, pp. 119-121. , "The Silver of Aryandes", The Journal of Egyptian Archaeology, Vol. 24, No. 2, 1938, pp. 245-246. 
"Trade between Greece and Egypt before Alexander the Great", The Journal of Egyptian Archaeology, Vol. 25, No. 2 (Dec., 1939), pp. 177-183.

Muhs, B., The Ancient Egyptian Economy: 3000-30 BCE, Cambridge, Cambridge University Press, 2016.

Noe, S.P., “A bibliography of Greek coin hoards”, Numismatic Notes and Monographs, No. 25, 1925, pp.1-277.

Reden, S.V., Money in Ptolemaic Egypt from the Macedonian Conquest to the End of the Third Century BC., Cambridge, Cambridge University Press, 2010.

, "Money, Law and Exchange: Coinage in the Greek Polis", The Journal of Hellenic Studies, Vol. 117 (1997), pp. 154-176.

Ridgeway, W., Origin of Metallic Currency and Weight Standards, Cambridge, Cambridge University Press, 1892.

Robens, E., Jayaweera, S.A. \& Kiefer, S., Balances: Instruments, Manufacturers, History, Heidelberg, London, Springer, 2014.

Robertson, D.H., Money, Chicago, University of Chigaco Press, 1962.

Robinson, E. S. G., A Find of Archaic Greek Coins from the Delta, The Numismatic Chronicle and Journal of the Royal Numismatic Society, Fifth Series, Vol. 10, No. 38, 1930, pp. 93-106.

, "A Hoard From "Sidon" [Beni-Hassan]", The

Numismatic Chronicle and Journal of the Royal Numismatic Society, Fifth Series, Vol. 17, No. 67, 1937, pp. 197-199.

Robinson, E. S. G., "The Tell El-Mashkuta Hoard of Athenian Tetradrachms", The Numismatic Chronicle and Journal of the Royal Numismatic Society, Sixth Series, Vol. 7, No. 3/4 (1947), pp. 115121. 
Roebuck, C., "The Grain Trade between Greece and Egypt", Classical Philology, Vol. 45, No. 4 (Oct., 1950), pp. 236-247.

Roy, D., The Power of Money, India, New Delhi, 2011.

Sacks, D.H., "The Blessings of Exchange in the Making of the Early English Atlatic", in: Religion and Trade: Cross-Cultural Exchanges in World History, 1000-1900, ed. by: Trivellato, F., Halevi, L., and Antunes, C., USA, Oxford University Press, 2014.

Samuel, AE., The Money Economy and the Ptolemaic Peasantry, The Bulletin of the American Society of Papyrologists, Vol. 21, No. 1/4 (1984), pp. 187-206.

Schaps, D., The Invention of Coinage and the Monetization of Ancient Greece, USA, University of Michigan, p. 50.

Seltman, C., Greek Coins, A History Of Metallic Currency And Coinage Down To The Fall of The Hellenistic Kingdoms, London, Methuen \& Co. LTD, 1965, p.5.

Spier, J., Potts, T.F., \& Cole, S.E, Beyond the Nile: Egypt and the Classical World, Los Angeles, Getty Publications, 2018, p.27.

Stiebing, W.H., "The End of the Mycenean Age", The Biblical Archaeologist, Vol. 43, No. 1 (Winter, 1980), pp. 7-21.

Sutherland, C. H. V., "Corn and Coin: A Note on Greek Commercial Monopolies", The American Journal of Philology, Vol. 64, No. 2 (1943), pp. 129-147.

Thompson, M., Mørkholm, O., and Kraay, C.M., An Inventory of Greek Coin Hoards, New York: Publ. for the International Numismatic Commission by the American Numismatic Society, 1973. 
Van Alfen, P.G., "A New Athenian "Owl" and Bullion Hoard from the Near East", American Journal of Numismatics (1989), Vol. 16/17 (2004-05), pp. 47-61.

in Persian-Period Egypt", American Journal of Numismatics, Vol. 16/17, 2004-05, pp. 7-46.

Walter Donlan, "The Unequal Exchange between Glaucus and Diomedes in Light of the Homeric Gift Economy”, Phoenix, Vol. 43, No. 1 (Spring, 1989), pp. 1-15.

Weber, H., "On Finds of Archaic Greek Coins in Lower Egypt", The Numismatic Chronicle and Journal of the Numismatic Society, Third Series, Vol. 19, 1899, pp. 269-287.

White, J. E. M., Ancient Egypt: Its Culture and History, New York, Dover Publications, 2013, p.47.

Yang, B., "The Rise and Fall of Cowrie Shells: The Asian Story", Journal of World History, Vol. 22, No. 1 (March 2011), pp. 1-25. 


\section{Plate I*}

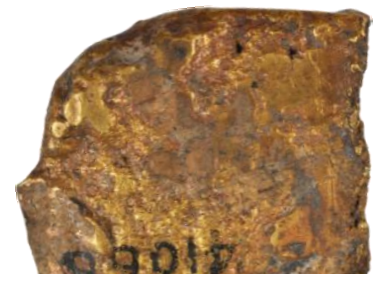

No

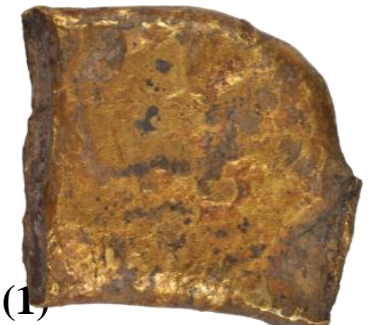

Fragmentary gold rectangular slab $(42 \mathrm{gm}-30 \times 26 \mathrm{~mm})$

Egyptian museum in Cairo (Sr. No. 817)

The diameter is measured at the widest point
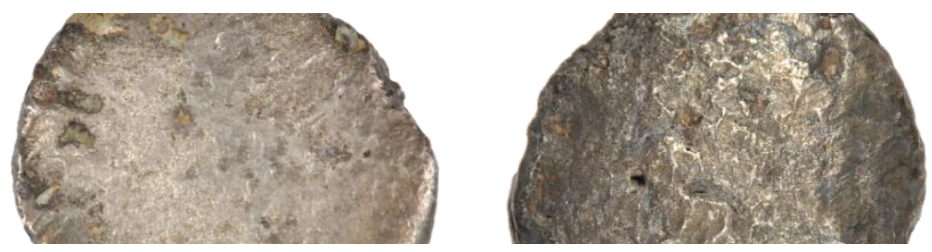

No (2)

Quasi-round silver cake ingot (64 gm-37mm)

Egyptian museum in Cairo (Sr. No. 808)

The diameter is measured at the widest point

\section{Plate I]}

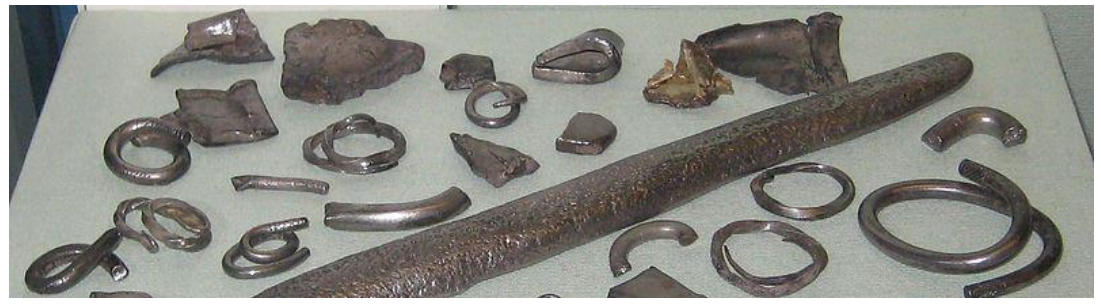

Fig. 1

Part of Tal El-Amarna hoard, Egypt, circa 1850-1800 BCE

(18th dynasty)

https://commons.wikimedia.org/wiki/File:British_Museum_el-

Amarna Hoard.jpg

* I am deeply museum for th

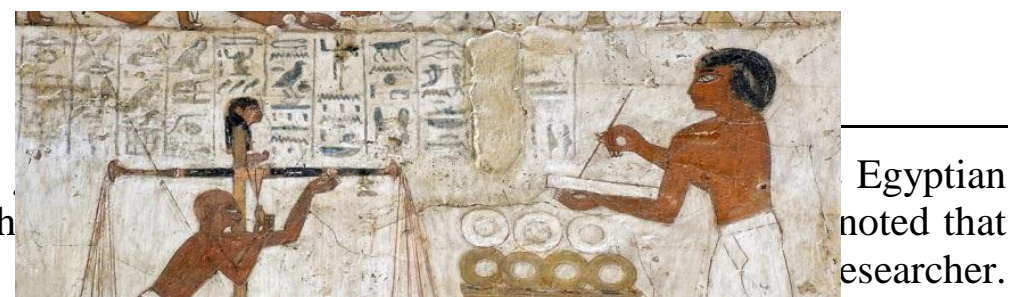


Fig. 2

Ancient Egyptian gold and silver rings being weighed.

Rekhmire's tomb at Luxor.

https://paulsmit.smugmug.com/Features/Africa/Egypt-Luxortombs/i-vt9L8qi

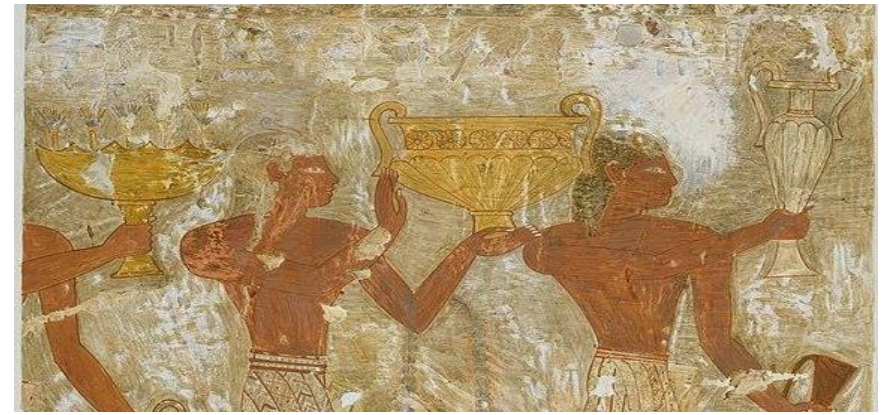

Fig. 3

Cretans Bringing Gifts, from Tomb of Rekhmire ( Facsimile)

New Kingdom (circa 1479 -1425 B.C.)

https://commons.wikimedia.org/wiki/File:Cretans_Bringing_Gifts,_Tomb_of

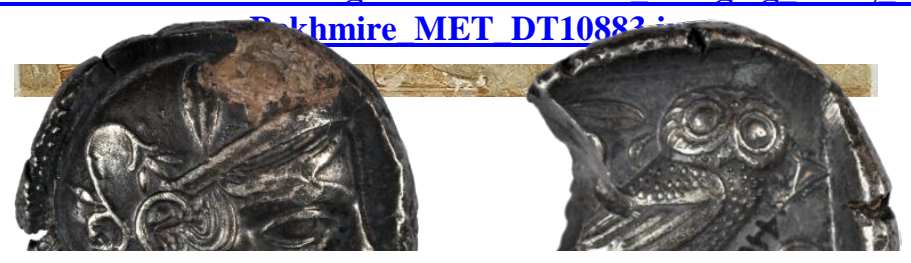

Fig. 4

Clipped Athenian tetradrachm from the Egyptian museum in

Cairo ( ${ }^{\text {th }}$ section)

El-Khachab, M.A.M., op.cit., pl. l.

(Photographed by the researcher from the Egyptian museum) 